\title{
DIABETIC MACULAR EDEMA: TRADITIONAL AND NOVEL TREATMENT
}

\author{
Martina Tomić ${ }^{1}$, Romano $\operatorname{Vrabec}^{1}$, Tamara Poljičanin $^{2}$, Spomenka Ljubić ${ }^{3}$ and Lea Duvnjak ${ }^{3}$
}

\author{
${ }^{1}$ Department of Ophthalmology, Vuk Vrhovac University Clinic for Diabetes, \\ Endocrinology and Metabolic Diseases, Merkur University Hospital; ${ }^{2}$ Croatian National Institute of Public Health; \\ ${ }^{3}$ Department of Diabetes and Endocrinology, Vuk Vrhovac University Clinic for Diabetes, \\ Endocrinology and Metabolic Diseases, Merkur University Hospital, Zagreb, Croatia
}

\begin{abstract}
SUMMARY - Diabetes is one of the leading public health problems worldwide. Diabetic macular edema (DME) is the main cause of vision loss in patients with diabetes. Ideal metabolic control of diabetes is the primary goal of treatment and the basic way of preventing and stopping the progression of DME. Although laser photocoagulation has been the standard treatment of DME for nearly three decades, superior outcomes can be achieved with novel, intravitreal anti-VEGF and steroid therapy. Novel treatment option for DME depends on visual acuity and location/extent of macular thickening based on optical coherence tomography scans. According to the International Clinical Classification Scale, DME is divided into no center-involving DME and center-involving DME (CI-DME). New guidelines recommend intravitreal treatment as the treatment of choice for patients with CI-DME and moderate visual impairment. Patients with no CI-DME and mild visual impairment should be treated with modified ETDRS laser photocoagulation and closely observed. Vitrectomy is the treatment of choice for patients with a tractional component of DME. Nowadays, traditional treatment goal of preventing blindness in patients with DME has been changed by the new goal aiming to restore impaired vision, prevent further vision loss and improve visual function. Therefore, many trials addressing this new concept have been underway worldwide.
\end{abstract}

Key words: Diabetes mellitus; Macular edema; Laser photocoagulation; Vitrectomy

\section{Introduction}

Diabetes is the most common endocrine disease in developed countries and one of the most common non-communicable diseases globally, estimated to have affected more than 415 million people in 2015 and projected to affect 642 million by $2040^{1}$. The existing burden of disease, high prevalence and incidence, life course characterized by development of chronic complications, decreased quality of life and increased cost of health care make diabetes one of the leading

Correspondence to: Martina Tomic, MD, PhD, Department of Ophthalmology, Vuk Vrhovac University Clinic for Diabetes, Endocrinology and Metabolic Diseases, Merkur University Hospital, Dugi dol 4a, HR-10000 Zagreb, Croatia

E-mail:martina.tomic@idb.hr

Received November 24, 2016, accepted December 29, 2016 public health problems worldwide. Diabetes deaths have almost doubled in the last two decades worldwide $^{2}$. In 2012, diabetes directly caused 1.5 million deaths $^{3}$, while as much as 5 million deaths were attributable to diabetes, accounting for $14.5 \%$ of global allcause mortality among adults ${ }^{1}$. High blood glucose is the $3^{\text {rd }}$ most important risk factor for premature mortality ${ }^{4}$, and diabetes is the $9^{\text {th }}$ leading cause of disability worldwide ${ }^{5}$. In the last decades, one of the greatest increases in years lived with disability (YLDs) was observed in diabetes, especially in diabetes complications, among which the highest increase of $36.7 \%$ was observed for vision loss due to diabetes ${ }^{5}$. In diabetes, vision loss is most commonly the result of diabetic retinopathy (DR) and diabetic macular edema (DME) frequent diabetes complications present in as much as $34.6 \%$ and $6.81 \%$ of patients with diabetes, respective- 
ly. DME, but not $\mathrm{DR}$ per se, is nowadays the main cause of vision loss in patients with diabetes ${ }^{7}$. Although estimations may differ upon the diagnostics used $^{8}$, studies revealed up to 21 million DME and 28 million vision threatening $\mathrm{DR}^{7}$.

Diabetic macular edema is a special form of diabetic retinopathy, a highly specific microvascular complication of diabetes on the eyes. DME is thickening of the retina within two diameters of the optic nerve from the center of the macula, functionally the most important part of the eye ${ }^{9}$. It is caused by breakdown of the blood-retinal barrier, abnormal microvascular permeability and consequent leakage of fluid and plasma constituents into the layers of the macula ${ }^{10}$. Structural changes of DME are characterized by the accumulation of liquid and hard exudates in the outer plexiform and inner nuclear layers of the macula and formation of fluid-filled cystoid spaces.

Morphologically, macular edema may be focal and diffuse. Focal edema is well-circumscribed macular thickening associated with complete or incomplete rings of hard exudates caused by leakage from one or more individual microaneurysms. Diffuse edema is diffuse macular thickening caused by widespread leakage from dilated and abnormally permeable capillaries. Unlike focal edema, diffuse edema is less surrounded by hard lipid exudates, but more often due to widespread leakage by marked damage to macular architecture and development of cystoid spaces. Especially significant edema, because of its impact on the central vision, is edema located within $500 \mu \mathrm{m}$ of the center of the macula (clinically significant macular edema).

\section{Risk Factors for DME}

Diabetic macular edema develops and progresses as a result of the interaction of different non-modifiable and modifiable risk factors.

Diabetes duration is the most important non-modifiable risk factor directly associated with the incidence and prevalence of DME in patients with both types of diabetes. The Wisconsin Epidemiologic Study of Diabetic Retinopathy (WESDR) in the USA found that $20 \%$ of patients with type 1 diabetes and $14 \%-25 \%$ of patients with type 2 diabetes developed DME over a 10 -year follow up period ${ }^{11}$. Data from the 25 -year follow up of the WESDR cohort found that the cumulative incidence of DME was $29 \%{ }^{12,13}$. Although the cu- mulative incidence of DME increased with duration of diabetes, the correlation was not linear, presumably due to the increased competing risk of death.

Hyperglycemia is the strongest modifiable risk factor for the development and progression of DR and DME. The Diabetes Control and Complications Trial (DCCT) in type 1 diabetes and the United Kingdom Prospective Diabetes Study (UKPDS) in type 2 diabetes found that tighter control of glycemia $\left(\mathrm{HbA}_{1} \mathrm{c}\right.$ $\leq 7 \%$ ) significantly reduced the risk of development and progression of DR, DME, vitreal hemorrhage and need for laser treatment, as well as the risk of blindness ${ }^{14,15}$. The DCCT also found that intensive glycemic control was associated with $46 \%$ reduction in the incidence of DME at the end of the trial and 58\% reduction 4 years later compared with those in the conventional group ${ }^{16}$.

Hypertension is also an important modifiable risk factor for $\mathrm{DME}^{12,13}$. Each $10-\mathrm{mm} \mathrm{Hg}$ increase in systolic blood pressure was associated with an approximately $15 \%$ additional risk of $\mathrm{DME}^{17}$. In the UKPDS, patients with hypertension with tight blood pressure control had a $34 \%$ reduction in the rate of progression of DME and $47 \%$ reduction in deterioration of visual acuity $(\mathrm{VA})^{18}$. Some clinical trials also showed that specific blood pressure-lowering medications that target the renin-angiotensin system had additional beneficial effects on DR and DME, independently of their hypotensive actions ${ }^{19,20}$.

Dyslipidemia has a significant role in the pathogenesis of DME; some studies report that serum lipids were independently associated with $\mathrm{DME}^{21}$. The Fenofibrate Intervention and Event Lowering in Diabetes (FIELD) study showed that fenofibrate reduced the frequency of laser treatment for DME by $31 \%$ in type 2 diabetes ${ }^{22}$. Notably, the finding in the FIELD study appeared not only to be attributable to measurable changes in lipid profile, suggesting that other as yet unknown mechanisms could contribute to the protective effect of fenofibrate ${ }^{22}$.

Other non-modifiable and modifiable risk factors are puberty, pregnancy, genetic factors, nephropathy, obesity ${ }^{23}$ and smoking.

\section{Traditional Treatment of DME}

Ideal metabolic control of diabetes, assuming strict control of well-known modifiable risk factors of hy- 
perglycemia, hypertension, dyslipidemia and others, is the primary goal of treatment and the basic way of preventing and stopping the progression of $\mathrm{DME}^{14,15,22,24,25}$.

Laser photocoagulation has been the primary treatment for DME since the early 1980s. The role of laser in preventing visual loss and blindness due to DME was established in 1970s-1980s by two large studies, the Diabetic Retinopathy Study (DRS) ${ }^{26}$ and the Early Treatment Diabetic Retinopathy Study $(\text { ETDRS })^{27,28}$. Laser photocoagulation was performed as focal treatment of microaneurysms and other areas of focal leakage with a 50-100 $\mu \mathrm{m}$ spot size to obtain definite whitening around the area of leakage, or as grid treatment of abnormally permeable capillaries and other areas of diffuse leakage within two disc diameters of the center using spot sizes of 50-200 $\mu \mathrm{m}$ and a space of one burn width apart. The ETDRS demonstrated that photocoagulation reduced the risk of moderate vision loss caused by DME in about 50\% of the eyes, in only $3 \%$ of eyes this therapy led to improvement of VA, and in the rest VA unfortunately remained poor due to persistence of macular edema ${ }^{27,28}$. The ETDRS also indicated that laser treatment was neither ideal therapy nor possible in every single eye with DME. The potential complications of macular laser include laser scar expansion, paracentral scotomata, elevation of central visual field thresholds, secondary choroidal neovascularization and subretinal fibrosis $^{29,30}$.

\section{Novel Treatment Options for DME}

Nowadays, the DRCR Network group recommends a modified ETDRS focal/grid laser regimen as follows: all leaking microaneurysms 500 to $3000 \mu \mathrm{m}$ from fovea should be treated directly with $50 \mu \mathrm{m}$ spot size, duration $0.05-0.1 \mathrm{~s}$ and intensity to achieve grayish reaction; grid treatment should be performed to areas of retinal thickening from 500 to $3000 \mu \mathrm{m}$ superiorly and inferiorly and to $3500 \mu \mathrm{m}$ temporally with a space of two burns width apart ${ }^{31}$.

Subthreshold micropulse diode laser photocoagulation is a treatment that theoretically avoids damaging the inner neurosensory retina, thereby reducing potential complications such as paracentral scotomata and enlargement of post-treatment scars. This technique was first described in the late 1990s and since then there has been some randomized controlled trials (RCTs) comparing this technique to modified ETDRS laser treatment ${ }^{32,33}$. In their trial, Vujosevic et al. found improvement of central retinal sensitivity in the micropulse group, but its deterioration in the modified ETDRS group ${ }^{34}$. Micropulse laser thus may offer a new, less aggressive laser approach in the treatment of clinically significant macular edema.

Corticosteroids are potent anti-inflammatory agents that can counteract many of the pathological processes thought to play a role in the development of macular edema. They prevent leukocyte migration, reduce fibrin deposition, stabilize endothelial cell tight junctions, and inhibit synthesis of vascular endothelial growth factor (VEGF), prostaglandins and proinflammatory cytokines ${ }^{35,36}$. The first reports on the use of intravitreal corticosteroid injection for DME were published in 2001-2002 37,38 , suggesting that intravitreal triamcinolone (IVTA) is potentially an effective treatment for DME. This treatment has gained widespread use as an off-label agent in a number of ocular diseases, including DME, most commonly at a dose of $4 \mathrm{mg}$ of triamcinolone acetonide (Kenalog ${ }^{\circledR}$; BristolMyers Squibb, Princeton, NJ, USA), despite the lack of data from a controlled study demonstrating its safety and efficacy. Recently, the DRCR.net found that IVTA had best effect on VA improvement within 4 months of the application and that this effect was transient ${ }^{39}$. A longer-lasting and doubling effect on VA was achieved only by using the IVTA plus focal/grid laser treatment ${ }^{40}$. The IVTA treatment is considerably limited by adverse events, high incidence of cataract formation and raised intraocular pressure ${ }^{40}$, and difficulty in delivering effective doses of therapeutic agents into the vitreous cavity. In recent years, development of a sustained-release intravitreal dexamethasone implant (Ozurdex ${ }^{\circledR}$, Allergan Inc., Irvine, CA, USA) has allowed more controlled delivery of the drug with a potentially lower rate of adverse events ${ }^{41}$. In a study evaluating the safety and efficacy of dexamethasone implant versus observation in the eyes with persistent DME, treatment with intravitreal dexamethasone implant was well-tolerated and produced significant improvements in VA, central retinal thickness (CRT) and fluorescein leakage compared with observation ${ }^{42}$. In 2014, the US Food and Drug Administration (FDA) approved Ozurdex (dexamethasone intravitreal implant) for use in adult patients with DME who have 
an artificial lens implant or are scheduled for cataract surgery. This makes Ozurdex the first corticosteroid approved for use in certain DME patients.

Another novel treatment approach, available for less than a decade, is the use of intravitreal therapies targeting vascular endothelial grown factor $(\mathrm{VEGF})^{43}$, the most potent known promoter of vascular permeability $^{44}$. Clinical studies have established that VEGF levels are elevated in eyes with $\mathrm{DME}^{45}$ and preclinical studies found correlation between increased VEGF level and the breakdown of the blood-retinal barrier ${ }^{46}$. Several mechanisms are believed to underlie these actions, i.e. VEGF directly acts on the permeability of intact blood vessels and promotes influx of inflammatory cells, thus leading to endothelial cell apoptosis in retinal vasculature ${ }^{47}$. Four VEGF-binding agents are currently used for ocular diseases: pegaptanib, bevacizumab (off-label), ranibizumab and aflibercept.

Pegaptanib (Macugen ${ }^{\circledR}$; Eyetech Pharmaceuticals, Inc. and Pfizer Inc., New York, USA) is a pegylated aptamer that targets the $\mathrm{VEGF}_{165}$ isoform. In 2004, it was approved by the FDA for the treatment of wet age-related macular degeneration and was the first anti-VEGF agent reported to have efficacy in the treatment of DME. The Macugen Diabetic Retinopathy Study Group conducted a phase II RCT of pegaptanib for fovea-involving $\mathrm{DME}^{48}$. The pegaptanibtreated eyes had better VA, greater reduction in CRT and less need for laser compared to the sham group. More recently, data from phase II/III RCT showed that pegaptanib was associated with improved VA in patients with DME for up to 2 years ${ }^{49}$. However, Pfizer pharmaceuticals are no longer pursuing further studies of pegaptanib in DME.

Bevacizumab (Avastin ${ }^{\circledR}$; Genentech, South San Francisco, CA, USA) is a full-length humanized monoclonal G1 antibody that inactivates all VEGF isoforms and is indicated for systemic use as an adjunct cancer chemotherapeutic agent ${ }^{50}$. In ophthalmology, bevacizumab has emerged as a therapeutic agent for retinal vascular diseases ${ }^{51}$ and has been used as an off-label agent in a number of ocular diseases, including $\mathrm{DR}$ and $\mathrm{DME}^{52}$. There have been a number of published trials with short follow up and using different treatment doses/regimens and different comparison groups that investigated the effect of bevacizumab in $\mathrm{DME}^{53}$. The BOLT study compared intravitreal bevacizumab to focal laser and found superior
VA results at 12 months (+ 8 vs. -0.5 letters), 5.1 times greater odds of gaining $>10$ letters, and a decrease in CRT $(130 \mu \mathrm{m}$ vs. $68 \mu \mathrm{m})$ in bevacizumab versus laser group $^{54}$. Ranibizumab (Lucentis ${ }^{\circledR}$; Genentech, South San Francisco, CA, USA) is a humanized antibody fragment directed at all isoforms of VEGF-A and is fabricated specifically for intravitreal use. FDA approved ranibizumab for the treatment of DME in 2012 and for the treatment of DR in February 2015. Evidence for DME treatment with ranibizumab is based on data from phase II and III RTCs, including the Safety and Efficacy of Ranibizumab in DME (RESOLVE) ${ }^{55}$; Ranibizumab for Edema of the mAcula in Diabetes (READ-2) 56 ; Core Study to Assess the Efficacy and Safety of Ranibizumab Intravitreal Injections (RESTORE) ${ }^{57}$; Diabetic Retinopathy Clinical Research Network (DRCR.net) Protocol $\mathrm{I}^{58}$ and Study of Ranibizumab Injection in Subjects with CSDME Secondary to Diabetes (RISE and RIDE) ${ }^{59}$.

Aflibercept $\left(\right.$ Eylea $^{\circledR}$; Bayer Healthcare Pharmaceuticals, Berlin, Germany) is a $115-\mathrm{kDA}$ recombinant fusion protein consisting of the VEGF binding domains of human VEGF receptors 1 and 2 fused to the Fc domain of human immunoglobulin-G160. Animal studies demonstrated intravitreal aflibercept to have theoretic advantages over bevacizumab and ranibizumab, including longer half-life in the eye and higher binding affinity to VEGF-A ${ }^{61}$. In addition, the fusion protein binds PGF 1 and 2, which have been shown to contribute to excessive vascular permeability and retinal neovascularization ${ }^{62}$. In 2014, FDA approved aflibercept for the treatment of DME and in March 2015 for the treatment of DR in patients with DME. Evidence for DME treatment with aflibercept is based on data from phase II and III RCTs, including the DME and VEGF Trap-Eye: INvestigation of Clinical Impact (DA VINCI) study ${ }^{63}$; Study of VEGF Trap-Eye in Vision Impairment due to DME (VIV$\left.\mathrm{ID}^{\mathrm{DME}}\right)$ and Intravitreal Administration of VEGF Trap-Eye in Patients with DME (VISTA $\left.{ }^{\mathrm{DME}}\right)^{64}$. More recently, data from the DRCR.net Protocol T showed that intravitreal aflibercept, bevacizumab and ranibizumab improved vision in eyes with center-involved DME, but the relative effect depended on baseline VA. When the initial VA loss was mild, there were no differences among study groups. At worse levels of initial VA, aflibercept was more effective in improving vi$\operatorname{sion}^{65}$. 
All intravitreal anti-VEGF agents were generally well tolerated in all studies. The most commonly reported ocular serious adverse events were endophthalmitis and increased intraocular pressure. Systemic adverse events in patients having received anti-VEGF for $\mathrm{DME}$ occurred at rates equal to those in patients that received laser treatment or sham injection. The incidence of cardiovascular events and arterial thromboembolism reported in these studies was low, possibly because high-risk patients were excluded.

Surgical vitrectomy as a novel treatment of DME is indicated in widespread/diffuse DME that is refractory to laser and intravitreal treatment, and is caused by vitreous traction in association with visual impairment. In their study of vitrectomy for DME, Haller et al. found improvement of VA by $\geq 10$ letters in $38 \%$, reduction in central subfield thickness to $<250 \mu \mathrm{m}$ in $50 \%$ of patients, and reduction of thickness of $\geq 50 \%$ in most of the eyes ${ }^{66}$.

\section{Guidelines for Treatment of DME}

Treatment of DME depends on VA and location/ extent of macular thickening based on optical coherence tomography (OCT) scans, and the guidelines provide paradigms based on the classification scale, current evidence and consensus of opinion ${ }^{67-69}$. According to the International Clinical Classification Scale, DME is divided into no center-involving DME and center-involving DME, confirmed with OCT, which is not explained by thickening from an epiretinal membrane ${ }^{70}$. Visual acuity 6/9 (0.7) and OCT central subfield thickness $>250 \mu \mathrm{m}$ are crucial when choosing a treatment option, also referring to the patient's individual circumstances.

No center-involving DME should be treated with a modified ETDRS focal/grid laser photocoagulation according to the following recommendations ${ }^{31}$ :

- direct focal photocoagulation of leaking microaneurysms 500 to $3000 \mu \mathrm{m}$ from fovea with 50$\mu \mathrm{m}$ spot size, duration $0.05-0.1 \mathrm{~s}$ and intensity to achieve grayish reaction, and

- grid photocoagulation of areas of retinal thickening from 500 to $3000 \mu \mathrm{m}$ superiorly and inferiorly and to $3500 \mu \mathrm{m}$ temporally with barely visible 200-300 burns size 50-100 $\mu \mathrm{m}$, duration 0.05-0.1 s and a space of two burns width apart.
The same treatment should be considered in center-involving DME with VA >6/9 (0.7), central subfield thickness $<250 \mu \mathrm{m}$ and microaneurysms located in areas accessible to laser. After the macular laser, 3 - to 4-month follow up is recommended as long as no other features are present that require other treatment option or more regular follow up.

Center-involving $\boldsymbol{D M E}$ with VA $>6 / 9$ (0.7) and central subfield thickness $>250 \mu \mathrm{m}$ should be treated with intravitreal anti-VEGF agents with or without macular laser. For phakic eyes unresponsive to these treatments, intravitreal dexamethasone implant may be considered, bearing in mind the potential side effects. The same treatment should be undertaken in center-involving DME with VA 6/9-6/10 (0.7 to 0.6) or worse and central subfield thickness $>250 \mu \mathrm{m}$. For pseudophakic eyes, IVTA or dexamethasone implant with or without laser may also be considered. AntiVEGF treatment regimen includes initial loading phase of monthly injections for 4-6 months, followed by PRN phase with continued treatment until the macula is dry or until there is no further improvement. Monthly follow up of patients undergoing anti-VEGF treatment with VA assessment and OCT scan is required to decide on re-treatments. For patients undergoing intravitreal steroid treatment, regular monitoring of intraocular pressure is also required. If the patient has been stable off treatment for several monthly assessments, the period between follow up appointments may be increased gradually to a maximum of 3-4 months as long as there are no other features requiring more frequent follow up. Center-involving DME with VA $<6 / 12(0.5)$ and central subfield thickness $>250 \mu \mathrm{m}$ should be observed, especially if longstanding and no response to previous laser, or if there is huge macular ischemia. Otherwise, anti-VEGF or steroid treatment may be considered after careful consultation. Center-involving DME with vitreomacular traction is an indication for vitrectomy with or without intravitreal anti-VEGF or steroid treatment.

\section{Conclusion}

Diabetic macular edema is a significant public health challenge. Many patients are undiagnosed and untreated, and even those treated with standard laser therapy may respond poorly and progressively lose vi- 
sion. Although laser photocoagulation has long been the primary treatment for preventing blindness in patients with DME, treatment goals should now aim to restore impaired vision, prevent further vision loss and improve visual function. Better knowledge of the pathophysiology of DME and recent RCTs suggest that these goals can be achieved using novel treatment options, intravitreal anti-VEGF and corticosteroidbased therapy, with a well-documented tolerable safety profile. As a result of these recent data, the intravitreal anti-VEGF agents and steroids are suggested as firstline treatment in place of laser photocoagulation in DME causing vision loss. New guidelines recommend intravitreal treatment as the treatment of choice for patients with center-involving DME and moderate visual impairment. Patients with no center-involving DME and mild visual impairment should be treated with modified ETDRS focal/grid laser photocoagulation and closely observed. Vitrectomy is the treatment of choice for patients with a tractional component of DME. Undoubtedly, in the future patients might need various combinations of these therapies to obtain the best outcome; thus, many studies are already running to address this goal.

\section{References}

1. International Diabetes Federation (IDF). IDF Diabetes Atlas, $7^{\text {th }}$ edition. Brussels, Belgium, 2015 [Internet] (cited 13 January 2016). Available from: http://www.diabetesatlas.org/

2. Lozano R, Naghavi M, Foreman K, Lim S, Shibuya K, Aboyans $\mathrm{V}$, et al. Global and regional mortality from 235 causes of death for 20 age groups in 1990 and 2010: a systematic analysis for the Global Burden of Disease Study 2010. Lancet. 2012; 380(9859):2095-128. doi: 10.1016/S0140-6736(12)61728-0.

3. World Health Organization (WHO). Global Health Estimates: Deaths by Cause, Age, Sex and Country, 2000-2012. Geneva, Switzerland, World Health Organization, 2014.

4. World Health Organization (WHO). Global health risks: mortality and burden of disease attributable to selected major risks. Geneva, Switzerland, World Health Organization, 2009.

5. Vos T, Flaxman AD, Naghavi M, Lozano R, Michaud C, Ezzati $\mathrm{M}$, et al. Years lived with disability (YLDs) for 1160 sequels of 289 diseases and injuries 1990-2010: a systematic analysis for the Global Burden of Disease Study 2010. Lancet. 2012;380 (9859):2163-96. doi: 10.1016/S0140-6736(12)61729-2.

6. Klein BE. Overview of epidemiologic studies of diabetic retinopathy. Ophthalmic Epidemiol. 2007;14(4):179-83.

7. Yau JW, Rogers SL, Kawasaki R, Lamoureux EL, Kowalski JW, Bek T, et al. Global prevalence and major risk factors of dia- betic retinopathy. Diabetes Care. 2012;35(3):556-64. doi: 10.2337/dc11-1909.

8. Wang YT, Tadarati M, Wolfson Y, Bressler SB, Bressler NM. Comparison of prevalence of diabetic macular edema based on monocular fundus photography ws optical coherence tomography. JAMA Ophthalmol. 2015;30:1-7. doi: 10.1001/jamaophthalmol.2015.5332.

9. Albert DM, Jakobiec FA. Principles and Practice of Ophthalmology,. $2^{\text {nd }}$ ed. Philadelphia: WB Saunders Co., 2000.

10. Bhagat N, Grigorian RA, Tutela A, Zarbin MA. Diabetic macular edema: pathogenesis and treatment. Surv Ophthalmol. 2009;54(1):1-32. doi: 10.1016/j.survophthal.2008.10.001.

11. Klein R, Klein BE, Moss SE, Cruickshanks KJ. The Wisconsin Epidemiologic Study of Diabetic Retinopathy. XV The longterm incidence of macular edema. Ophthalmology. 1995;102 (1):7-16.

12. Klein R, Knudtson MD, Lee KE, Gangnon R, Klein BE. The Wisconsin Epidemiologic Study of Diabetic Retinopathy. XXII The twenty-five-year progression of retinopathy in persons with type 1 diabetes. Ophthalmology. 2008;115(11):185968. doi: 10.1016/j.ophtha.2008.08.023.

13. Klein R, Knudtson MD, Lee KE, Gangnon R, Klein BE. The Wisconsin Epidemiologic Study of Diabetic Retinopathy. XXIII The twenty-five-year incidence of macular edema in persons with type 1 diabetes. Ophthalmology. 2009;116(3): 497-503. doi: 10.1016/j.ophtha.2008.10.016.

14. Diabetes Control and Complications Trial (DCCT) research group. The effect of intensive treatment of diabetes on the development and progression of long-term complications in insulin-dependent diabetes mellitus. N Engl J Med. 1993;329 (14):977-86.

15. United Kingdom Prospective Diabetes Study (UKPDS) group. Intensive blood glucose control with sulphonylureas or insulin compared with conventional treatment and risk of complications in patients with type 2 diabetes (UKPDS 33). Lancet. 1998;352(9131):837-53.

16. Diabetes Control and Complications Trial/Epidemiology of Diabetes Interventions and Complications (DCCT/EDIC) research group. Retinopathy and nephropathy in patients with type 1 diabetes four years after a trial of intensive therapy. $\mathrm{N}$ Engl J Med. 2000;342:381-9.

17. Gallego PH, Craig ME, Hing S, Donaghue KC. Role of blood pressure in development of early retinopathy in adolescents with type 1 diabetes: prospective cohort study. BMJ. 2008; 337:a918. doi: 10.1136/bmj.a918.

18. Mohamed Q, Gillies MC, Wong TY. Management of diabetic retinopathy: a systematic review. JAMA. 2007;298(8):902-16.

19. Mitchell P, Wong TY, for the Diabetic Macular Edema Treatment Guideline Working Group. Perspective management paradigms for diabetic macular edema. Am J Ophthalmol. 2014;157(3):505-13.e1-8. doi: 10.1016/j.ajo.2013.11.012.

20. Mauer M, Zinman B, Gardiner R, Suissa S, Sinaiko A, Strand $\mathrm{T}$, et al. Renal and retinal effects of enalapril and losartan in 
type 1 diabetes. N Eng1 J Med. 2009;361:40-51. doi: 10.1056/ NEJMoa0808400.

21. Benarous R, Sasongko MB, Qureshi S, Fenwick E, Dirani M, Wong TY, et al. Differential association of serum lipids with diabetic retinopathy and diabetic macular edema. Invest Ophthalmol Vis Sci. 2011(10);52:7464-9. doi: 10.1167/iovs. 11-7598.

22. Keech AC, Mitchell P, Summanen PA, O'Day J, Davis TM, Moffilitt MS, et al. FIELD study investigators. Effect of fenofibrate on the need for laser treatment for diabetic retinopathy (FIELD study): a randomized controlled trial. Lancet. 2007; 370(9600):1687-97.

23. Bulum T, Blaslov K, Duvnjak L. The use of anthropometric measurements of obesity in prediction of microvascular complications in obese type 2 diabetic patients. Acta Clin Croat. 2016;55(2):217-23. doi:10.20471/acc.2016.55.02.06.

24. Schrier RW, Estacio RO, Mehler PS, Hiatt WR. Appropriate blood pressure control in hypertensive and normotensive type 2 diabetes mellitus: a summary of the ABCD trial. Nat Clin Pract Nephrol. 2007;3(8):428-38.

25. Gupta A, Gupta V, Thapar S, Bhansali A. Lipid-lowering drug atorvastatin as an adjunct in the management of diabetic macular edema. Am J Ophthalmol. 2004;137(4):675-82.

26. Diabetic Retinopathy Study (DRS) research group. Preliminary report on effects of photocoagulation therapy. Am J Ophthalmol. 1976;81(4):383-96.

27. Early Treatment Diabetic Retinopathy Study (ETDRS) research group. Photocoagulation for diabetic macular edema. Early Treatment Diabetic Retinopathy Study report number 1. Arch Ophthalmol. 1985;103(12):1796-806.

28. Early Treatment Diabetic Retinopathy Study (ETDRS) research group. Treatment techniques and clinical guidelines for photocoagulation of diabetic macular edema. Early Treatment Diabetic Retinopathy Study report number 2. Ophthalmology. 1987;94(7):761-74.

29. Schatz H, Madeira D, McDonald HR, Johnson RN. Progressive enlargement of laser scars following grid laser photocoagulation for diffuse diabetic macular edema. Arch Ophthalmol. 1991;109(11):1549-51.

30. Guyer DR, D‘Amico DJ, Smith CW. Subretinal fibrosis after laser photocoagulation for diabetic macular edema. Am J Ophthalmol. 1992:113(6):652-6.

31. Diabetic Retinopathy Clinical Research Network (DRCR.net) group; Fong DS, Strauber SF, Aiello LP, Beck RW, Callanan DG, Danis RP, et al. Comparison of the modified Early Treatment Diabetic Retinopathy Study and mild macular grid laser photocoagulation strategies for diabetic macular edema. Arch Ophthalmol. 2007;125(4):469-80.

32. Friberg TR. Infrared micropulsed laser treatment for diabetic macular edema - subthreshold versus threshold lesions. Semin Ophthalmol. 2001;16(1):19-24.

33. Figueira J, Khan J, Nunes S, Sivaprasad S, Rosa A, de Abreu JF, et al. Prospective randomized controlled trial comparing sub- threshold micropulse diode laser photocoagulation and conventional green laser for clinically significant diabetic macular edema. Br J Ophthalmol. 2009;93(10):1341-4. doi: 10.1136/ bjo.2008.146712.

34. Vujosevic S, Bottega E, Casciano M, Pilotto E, Convento E, Midena E. Microperimetry and fundus autofluorescence in diabetic macular edema: subthreshold micropulse diode laser versus modified early treatment diabetic retinopathy study laser photocoagulation. Retina. 2010;30(6):908-16. doi: 10.1097/ IAE.0b013e3181c96986.

35. Joussen AM, Smyth N, Niessen C. Pathophysiology of diabetic macular edema. Dev Ophthalmol. 2007;39:1-12.

36. Nauck M, Karakiulakis G, Perruchoud AP, Papakonstantinou $\mathrm{E}$, Roth M. Corticosteroids inhibit the expression of the vascular endothelial growth factor gene in human vascular smooth muscle cells. Eur J Pharmacol. 1998;341(2-3):309-15.

37. Jonas JB, Sofker A. Intraocular injection of crystalline cortisone as adjunctive treatment of diabetic macular edema. Am J Ophthalmol. 2001;132(3):425-7.

38. Martidis A, Duker JS, Greenberg PB, Rogers AH, Puliafito CA, Reichel E, et al. Intravitreal triamcinolone for refractory diabetic macular edema. Ophthalmology. 2002;109(5):920-7.

39. Diabetic Retinopathy Clinical Research Network (DRCR.net) group. A randomized trial comparing intravitreal triamcinolone acetonide and focal/grid photocoagulation for diabetic macular edema. Ophthalmology. 2008;115(9):1447-9, 1449. e1-10. doi: 10.1016/j.ophtha.2008.06.015.

40. Gillies MC, McAllister IL, Zhu M, Wong W, Louis D, Arnold $\mathrm{JJ}$, et al. Intravitreal triamcinolone prior to laser treatment of diabetic macular edema: 24-month results of a randomized controlled trial. Ophthalmology. 2011;118(5):866-72. doi: 10.1016/j.ophtha.2010.09.029.

41. Herrero-Vanrell R, Cardillo JA, Kuppermann BD. Clinical applications of the sustained-release dexamethasone implant for treatment of macular edema. Clin Ophthalmol. 2011;5:139-46. doi: 10.2147/OPTH.S15783.

42. Haller JA, Kuppermann BD, Blumenkranz MS, Williams GA, Weinberg DV, Chou C, et al. Randomized controlled trial of an intravitreous dexamethasone drug delivery system in patients with diabetic macular edema. Arch Ophthalmol. 2010;128 (3):289-96. doi: 10.1001/archophthalmol.2010.21.

43. Nicholson BP, Schachat AP. A review of clinical trials of antiVEGF agents for diabetic retinopathy. Graefes Arch Clin Exp Ophthalmol. 2010;248(7):915-30. doi: 10.1007/s00417-0101315-z.

44. Senger DR, Connolly DT, Van de Water L, Feder J, Dvorak HF. Purification and NH2-terminal amino acid sequence of guinea pig tumor-secreted vascular permeability factor. Cancer Res. 1990;50(6):1774-8.

45. Funatsu H, Yamashita H, Sakata K, Noma H, Mimura T, Suzuki M, et al. Vitreous levels of vascular endothelial growth factor and intercellular adhesion molecule 1 are related to diabetic macular edema. Ophthalmology. 2005;112(5):806-16. 
46. Qaum T, Xu Q, Joussen AM, Clemens MW, Qin W, Miyamoto $\mathrm{K}$, et al. VEGF initiated blood-retinal barrier breakdown in early diabetes. Invest Ophthalmol Vis Sci. 2001;42(10): 2408-13.

47. Adamis AP, Berman AJ. Immunological mechanisms in the pathogenesis of diabetic retinopathy. Semin Immunopathol. 2008;30(2):65-84. doi: 10.1007/s00281-008-0111-x.

48. Cunningham ET Jr, Adamis AP, Altaweel M, Aiello LP, Bressler NM, D‘Amico DJ, et al. A phase II randomized double-masked trial of pegaptanib, an anti-vascular endothelial growth factor aptamer, for diabetic macular edema. Ophthalmology. 2005;112(10):1747-57.

49. Sultan MB, Zhou D, Loftus J, Dombi T, Ice KS. A phase 2/3, multicenter, randomized, double-masked, 2-year trial of pegaptanib sodium for the treatment of diabetic macular edema. Ophthalmology. 2011;118(6):1107-18. doi: 10.1016/j.ophtha.2011.02.045.

50. Van Meter ME, Kim ES. Bevacizumab: current updates in treatment. Curr Opin Oncol. 2010;22(6):586-91. doi: 10.1097/ CCO.0b013e32833edc0c.

51. Arevalo JF, Sanchez JG, Wu L, Maia M, Alezzandrini AA, Brito M, et al. Primary intravitreal bevacizumab for diffuse diabetic macular edema: the Pan-American Collaborative Retina Study Group at 24 months. Ophthalmology. 2009;116(8):148897.e1. doi: 10.1016/j.ophtha.2009.03.016.

52. Gunther JB, Altaweel MM. Bevacizumab (Avastin) for the treatment of ocular disease. Surv Ophthalmol. 2009;54(3):372400. doi: 10.1016/j.survophthal.2009.02.004.

53. Goyal S, Lavalley M, Subramanian ML. Meta-analysis and review on the effect of bevacizumab in diabetic macular edema. Graefes Arch Clin Exp Ophthalmol. 2011;249(1):15-27. doi: 10.1007/s00417-010-1452-4.

54. Michaelides M, Kaines A, Hamilton RD, Fraser-Bell S, Rajendram $\mathrm{R}$, Quhill $\mathrm{F}$, et al. A prospective randomized trial of intravitreal bevacizumab or laser therapy in the management of diabetic macular edema (BOLT study) 12-month data: report 2 . Ophthalmology. 2010;117(6):1078-86.e2. doi: 10.1016/j.ophtha.2010.03.045.

55. Massin P, Bandello F, Garweg JG, Hansen LL, Harding SP, Larsen M, et al. Safety and efficacy of ranibizumab in diabetic macular edema (RESOLVE Study): a 12-month, randomized, controlled, double-masked, multicenter phase II study. Diabetes Care. 2010;33(11):2399-405. doi: 10.2337/dc10-0493.

56. Nguyen QD, Shah SM, Khwaja AA, Channa R, Hatef E, Do $\mathrm{DV}$, et al. Two-year outcomes of the ranibizumab for edema of the macula in diabetes (READ-2) study. Ophthalmology. 2010;117(11):2146-51. doi: 10.1016/j.ophtha.2010.08.016.

57. Mitchell P, Bandello F, Schmidt-Erfurth U, Lang GE, Massin P, Schlingemann RO, et al:; for the RESTORE study group. The RESTORE study: ranibizumab monotherapy or combined with laser versus laser monotherapy for diabetic macular edema. Ophthalmology. 2011;118(4):615-25. doi: 10.1016/j. ophtha.2011.01.031.
58. Diabetic Retinopathy Clinical Research Network (DRCR.net) group; Elman MJ, Qin H, Aiello LP, Beck RW, Bressler NM, Ferris FL $3^{\text {rd }}$, et al. Intravitreal ranibizumab for diabetic macular edema with prompt versus deferred laser treatment: threeyear randomized trial results. Ophthalmology. 2012;119(11): 2312-8. doi: 10.1016/j.ophtha.2012.08.022.

59. Ip MS, Domalpally A, Hopkins JJ, Wong P, Ehrlich JS. Longterm effects of ranibizumab on diabetic retinopathy severity and progression. Arch Ophthalmol. 2012;130(9):1145-52. doi: 10.1001/archophthalmol.2012.1043.

60. Holash J, Davis S, Papadopoulos N, Croll SD, Ho L, Russell M, et al. VEGF-Trap: a VEGF blocker with potent antitumor effects. Proc Natl Acad Sci. USA 2002;99(17):11393-8.

61. Gaudreault J, Fei D, Rusit J, Suboc P, Shiu V. Preclinical pharmacokinetics of ranibizumab (rhuFabV2) after a single intravitreal administration. Invest Ophthalmol Vis Sci. 2005;46(2): 726-33.

62. Rakic JM, Lambert V, Devy L, Luttun A, Carmeliet P, Claes C, et al. Placental growth factor, a member of the VEGF family, contributes to the development of choroidal neovascularization. Invest Ophthalmol Vis Sci. 2003;44(7):3186-93.

63. Do DV, Nguyen QD, Boyer DS, Schmidt-Erfurth U, Brown DM, Vitti R, et al.; for the DA VINCI Study Group. One-year outcomes of the DA VINCI study of VEGF trap-eye in eyes with diabetic macular edema. Ophthalmology. 2012;119(8): 1658-65. doi: 10.1016/j.ophtha.2012.02.010.

64. Korobelnik J-F, Do DV, Schmidt-Erfurth U, Boyer DS, Holz FG, Heier JS, et al. Intravitreal aflibercept for diabetic macular edema. Ophthalmology. 2014;121(11):2247-54. doi: 10.1016/j. ophtha.2014.05.006.

65. Diabetic Retinopathy Clinical Research Network (DRCR.net) group; Wells JA, Glassman AR, Ayala AR, Jampol LM, Aiello LP, Antoszyk AN, et al. Aflibercept, bevacizumab, or ranibizumab for diabetic macular edema. N Engl J Med. 2015;372 (13):1193-203. doi: 10.1056/NEJMoa1414264.

66. Haller JA, Qin H, Apte RS, Beck RR, Bressler NM, Browning DJ, et al. Vitrectomy outcomes in eyes with diabetic macular edema and vitreomacular traction. Ophthalmology. 2010;117 (6):1087-93. e3. doi: 10.1016/j.ophtha.2009.10.040.

67. Royal College of Ophthalmologists (RCO). Diabetic Retinopathy Guidelines. London, UK: The Royal College of Ophthalmologists; 2012. Available at: www.rcophth.ac.uk.

68. American Academy of Ophthalmology (AAO) Retina/Vitreous Panel. Preferred Practice Pattern ${ }^{\circledR}$ Guidelines. Diabetic Retinopathy. San Francisco, CA: American Academy of Ophthalmology; 2014. Available at: www.aao.org/ppp.

69. Mitchell P, Wong TY. DIRECT new treatments for diabetic retinopathy. Lancet. 2008;372(9647):1361-3. doi: 10.1016/ S0140-6736(08)61413-0.

70. Wilkinson CP, Ferris FL 3rd, Klein RE, Lee PP, Agardh CD, Davis M, et al:; for the Global Diabetic Retinopathy Project Group. Proposed international clinical diabetic retinopathy and diabetic macular edema disease severity scales. Ophthalmology. 2003;110(9):1677-82. 
Sažetak

\section{DIJABETIČKI MAKULARNI EDEM:TRADICIONALNI I NOVI PRISTUP LIJEČENJU}

\section{Tomić, R. Vrabec, T. Poljičanin, S. Ljubići L. Duonjak}

Dijabetes je jedan od vodećih svjetskih javnozdravstvenih problema. Dijabetički makularni edem (DME) je glavni uzrok sljepoće u osoba oboljelih od dijabetesa. Idealna metabolička regulacija bolesti je primarni cilj liječenja i osnovni način sprječavanja i zaustavljanja progresije DME-a. Iako je laserska fotokoagulacija u posljednja tri desetljeća smatrana standardnim načinom liječenja DME-a, bolji ishod moguće je postići primjenom nove intravitrealne anti-VEGF ili steroidne terapije. Novi pristup liječenju DME-a ovisi o vidnoj oštrini i smještaju/veličini makularnog zadebljanja utvrđenog optičkom koherentnom tomografijom. Prema Međunarodnoj kliničkoj klasifikaciji DME se dijeli na DME koji ne zahvaća centar makule (ne CI-DME) i DME sa zahvaćenim centrom (CI-DME). Nove smjernice preporučuju intravitrealno liječenje kao prvi izbor liječenja za bolesnike s CI-DME i umjerenim padom vidne oštrine, dok bolesnike s ne CI-DME i blagim padom vidne oštrine treba liječiti modificiranom ETDRS laserskom fotokoagulacijom i pažljivo pratiti. Operativni zahvat vitrektomija izbor je liječenja bolesnika s trakcijski izazvanim DME-om. U današnje vrijeme je sprječavanje sljepoće kao tradicionalni cilj liječenja DME-a zamijenjen novim ciljevima, a to su oporavak oštećene vidne oštrine, sprječavanje daljnjeg slabljenja vida i poboljšanje vidne funkcije pa se danas u tu svrhu provode brojna znanstvena i klinička istraživanja širom svijeta.

Ključne riječi: Dijabetes melitus; Makularni edem; Laserska fotokoagulacija; Vitrektomija 